\title{
Synthesis and Properties of Poly(carbomethyloctylsiloxane)s by Melt Copolymerization of Bis(diethylamino)methyloctylsilane and Aryldiol Derivatives
}

\author{
Seung Beom Yun and Young Tae Park \\ Department of Chemistry, Keimyning University, Daegn 704-701, Korea. "E-mail: ytpark@kmu.ac.kr \\ Received September 3, 2008
}

\begin{abstract}
We carried out the melt copolymerizations of bis(diethylamino)methyloctylsilane with several aryldiols to afford poly(carbomethyloctylsiloxane)s containing fluorescent aromatic chromophore groups in the polymer main chain: poly(oxybiphenyloxymethyloctyl silane), poly(oxy(4,4'-isopropylidene)diphenyleneoxymethyloctylsilane), poly(oxy(4,4'-hexafluoroisopropylidene)diphenyleneoxymethyloctylsilane), poly(oxy-2,6-naphthalenediyloxymethyloctylsilane), and poly(oxyphenyleneoxymethyloctylsilane). These materials are soluble in common organic solvents such as CIICl, and TIF. FTIR spectra of all the polymeric materials show the characteristic Si-O-C stretching frequencies at $1051-1082 \mathrm{~cm}^{-1}$. The polymers in TIF solution exhibit strong maximum absorption peaks at 263-341 nm with the strong maximum excitation peaks at 253-325 nm, and strong maximum fluorescence emission bands at $300-420 \mathrm{~nm}$. $\Lambda$ ccording to TG $\Lambda$ all the polymers are stable up to $200^{\circ} \mathrm{C}$ with weight loss of less than $9 \%$ in nitrogen.
\end{abstract}

Key Words : Polycarbosiloxanes, Absorption, Excitation, Fluorescence, Thermal stability

\section{Introduction}

Organic and silicon-bearing polymeric materials containing $\pi$-conjugated groups along the main chain as well as the side chain have been of great interest for their potential applications as photonic, electronic, ionic conductive, and ceramic materials. ${ }^{1-3}$ Fluorescent polymers have also attracted considerable interest for use in electroluminescent materials. ${ }^{4}$ For instance, polysiloxanes containing fluorophores such as pyrene or carbazole in the polymer side chain were synthesized by hydrosilation of poly(methylhydrosiloxane) with vinyl- or allyl-functionalized pyrene or carbazole and Pt catalyst in toluene at around $70^{\circ} \mathrm{C} .{ }^{5}$ Fluorescent polysiloxanes containing a fluorescent group such as anthryl, fluorenyl, naphthyl, quinoline, or quinaldyl along the polymer side chain were synthesized by dehydrogenative coupling reactions of the poly(methylhydrosiloxane) with fluorescent alcohols or phenols. ${ }^{6}$ Interestingly, the linear copolymers of silarylene-siloxane-diacetylene exhibit elastomeric properties with thermal stabilities up to $330^{\circ} \mathrm{C}$ in air. ${ }^{7}$ Some researchers have reported temperature dependence of the steady-state fluorescence of linear poly(methylphenylsiloxane) in dilute solution at temperatures below $-50^{\circ} \mathrm{C}$ in order to explain their photophysical properties theoretically. ${ }^{8}$

Recently, ladderlike poly(p-phenylenevinylene)s with silicon and carbon bridged $\pi$-conjugated framework have been prepared by intramolecular cyclization of mono(o-silylphenyl)acetylene, showing that the prepared polymers are intensely fluorescent in the visible region with the emission colors varying from blue to green to yellow. Also endcapped silole dendrimers on an ethenyl-phenyl carbosilane exhibit green to greenish-blue fluorescence. ${ }^{10}$

However, photoelectronic properties such as excitation and fluorescence emission of polycarbosiloxanes containing aromatic fluorphores along the polymer main chain have seldom been reported." Polymers containing polysiloxane segments and other organic backbones are of interest in production of a new type of hybrid polymers, ${ }^{12}$ which are expected to possess novel properties that can be adjusted in characteristics such as glass transition temperature and thermal stability. For example, a new type of polymerization involving the polycondensation reaction of dihydrosilanes with dialkoxysilanes was reported at or below room temperature in the presence of very low levels of $\mathrm{B}\left(\mathrm{C}_{6} \mathrm{~F}_{5}\right)_{3}$ to yield hybrid polysiloxanes with elimination of hydrocarbon as a byproduct. $^{13}$

The condensation of a dichlorosilane with a silanediol in the presence of triethylamine was reported to yield alternating cyclotetrasiloxanes readily. ${ }^{14.15}$ The interfacial polymerization of a dichlorosilane in a organic solvent as octane and a diol in 2,5-hexanedione was reported to produce poly[alkyl(aryl)oxysilanes] with low molecular weight. ${ }^{16}$

Recently, we examined the synthesis and, in particular, the electronic and thermal properties of oligomers containing the $\pi$-conjugated moiety $C=C-B-C=C$ and an organosilacyclic group along the polymer backbone by polyaddition reactions of 1,1-diethynyl-1-silacyclopent-3-enes with borane derivatives. ${ }^{17.18}$ We also reported the synthesis as well as the photoelectronic and thermal properties of polycarbosilanes containing diethynyl and organosilane groups such as poly(1,1-diethynyl-1-silacyclopent-3-enes and -1silacyclobutane) and poly(diethynyldialkyl and -diarylsilane)s by oxidative coupling reactions of diethynyl organosilane monomers. ${ }^{19.20}$ We had previously reported the preparation and excited-state energy dynamics of polycarbosilanes as well as polycarbogermanes containing 1,4bis(thiophene or phenylene)buta-1,3-diyne in the polymer backbone. ${ }^{21.22}$ With these results in mind, we have extended our study to the preparation and photoelectronic properties 
of fluorescent polycarbosiloxane materials.

We now report the melt copolymerizations of bis(diethylamino)methyloctylsilane (2) with several aryldiols such as 4,4-biphenol (3a), 4,4'-isopropylidenediphenol (3b), 4,4'hexafluoroisopropylidene)diphenol (3c), 2,6-dihydroxynaphthalene (3d), hydroquinone (3e) to yield poly(carbomethyloctylsiloxane)s containing a fluorescent aromatic chromophore group in the main chain, such as polyroxybiphenyloxymethyloctylsilane) (4a), poly(oxy(4,4'-isopropylidene)diphenyleneoxymethyloctylsilane) (4b), poly(oxy(4,4'-hexafluoroisopropylidene)diphenyleneoxymethyloctylsilane) (4c), poly(oxy-2,6-naphthalenediyloxymethyloctylsilane) (4d), and poly(oxyphenyleneoxymethyloctylsilane) (4e), respectively. In order to synthesize linear poly(carbomethyloctylsiloxane)s with high molecular weight we carried out the melt copolymerization method of 2 with aryldiols. The materials produced were characterized by FTIR, ' $\mathrm{H}$, ${ }^{13} \mathrm{C}$, and ${ }^{29} \mathrm{Si}$ NMR spectrophotoscopy in solution state as well as elemental analysis. These polycarbosiloxanes include fluorescent aromatic groups along the main chain. We wil] now focus on studying the photoelectronic and thermogravimetric properties of the prepared polymers by using excitation and fluorescence emission spectrophotometry as well as thermogravimetric analysis (TGA).

\section{Results and Discussion}

Synthesis of Monomers and Polymers. The solution polycondensation of 1,2-dichlorotetramethyldisilane with resorcinol in $N$-methyl-2-pyrrolidone or toluene was reported to yield polysiloxanes with low molecular. ${ }^{23}$ For the preparation of polycarbosiloxanes with high molecular weight we decided to use bis(diethylamino)methyloctylsilane (2) as a co-monomer in order to carry out melt copolymerization. The monomer 2 was readily prepared by the reaction of dichloromethyloctylsilane (1) with 4 equivalents of diethylamine under an argon atmosphere in a high yield (Scheme I).

The 'H NMR spectrum of 2 shows triplet and quartet resonances at 0.98 and $2.81 \mathrm{ppm}$, attributed to the ethyl group bonded to nitrogen. This indicates that the diethylamination reaction of the starting material 1 , the substitution reaction of two chlorine atoms with diethylamino groups, was complete under our reaction conditions using 4 equivalents of diethylamine. In the ${ }^{13} \mathrm{C}$ NMR spectrum of 2 , two carbon peaks of the ethyl group bonded to the nitrogen are observed at 15.50 and $39.16 \mathrm{ppm}^{24}$ In the ${ }^{29} \mathrm{Si} \mathrm{NMR}$ spectrum of 2 , the silicon resonance is observed at -4.71 ppm. ${ }^{25}$ We confirmed the molecular jon peak at the $m / z$ of 300 in the mass spectrum of 2 .

Melt copolymerization reaction between 1,2-bis(diethylamino)disilane and bisphenol has been reported to yield poly(oxyaryleneoxydisilane). ${ }^{23.26}$ We tried copolymerization by utilizing the functionalities of bis(diethylamino)methyloctylsilane 2 as a novel monomer according to the previously reported method. ${ }^{23}$ The melt copolymerizations of 2 with various diol derivatives $3 \mathbf{n}-\mathbf{e}$ have been carried out to afford poly(oxyaryleneoxysilane)s $4 a-e$, containing aromatic<smiles>CCCCCNCC</smiles>

1

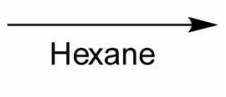

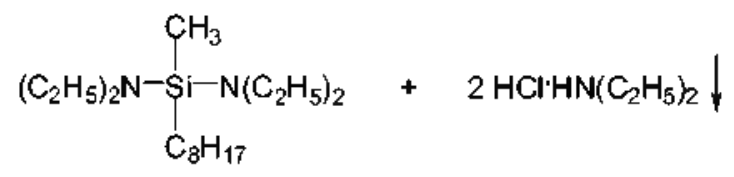

$2(75 \%)$

Scheme 1

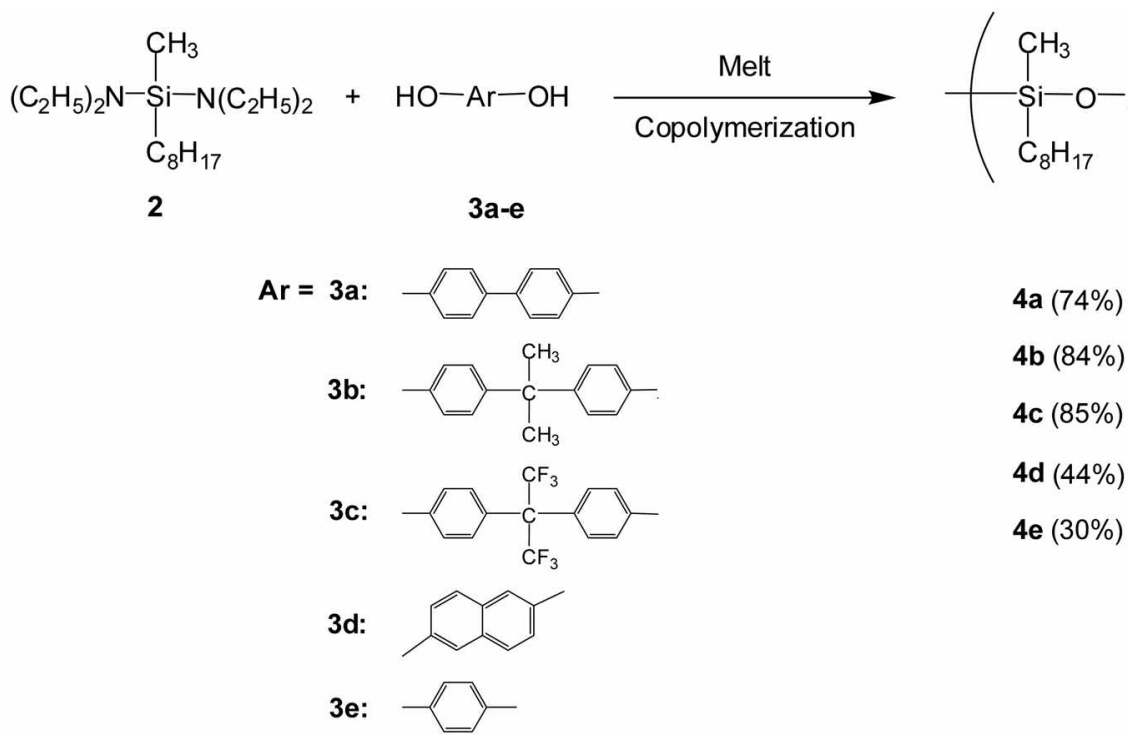


and organosilyl groups in the polymer main chain (Scheme 2).

The poly(oxyaryleneoxysilane)s 4a-e are dark brownish powders or very viscous liquids soluble in common organic solvents such as $\mathrm{CHCl}_{3}$ and THF. We have measured molecular weights of the polymers by gel permeation chromatography $(\mathrm{GPC})$. The number average molecular weights $\left(M_{n}\right)$ of materials 4a-e were observed in the range of 2,250-7,480 with polydispersities of 1.11-1.88 (Table 1), suggesting that the hybrids 4ale are oligomeric materials with low molecular weight. This seems to be explained by considering the rigidity of aromatic diols used as co-monomer. We characterized the resulting polymers by several spectroscopic methods such as ${ }^{1} \mathrm{H},{ }^{13} \mathrm{C},{ }^{29} \mathrm{Si} \mathrm{NMR}$, and FTIR spectra as well as by measuring optical properties such as absorption, excitation, and fluorescence emission spectra in solution. Some selected spectral properties of the polycarbosiloxanes 4i-e are listed in Table 1.

FTIR spectra of all the polymeric materials 4a-e show the characteristic Si-O-C stretching frequencies at 1070,1082 , 1051,1075 , and $1053 \mathrm{~cm}^{-1}$, indicating that $\mathrm{Si}-\mathrm{O}-\mathrm{C}$ bonds are formed through the copolymerization reactions. ${ }^{2+27}$ In particular, the ${ }^{29} \mathrm{Si}$ NMR spectra of the polymers 4a-e show that the major singlet resonance peaks appear at -9.21 , $-9.18,-9.13,-8.38$, and $-9.21 \mathrm{ppm}$, respectively, indicating that the silicon atoms in the polymer main chain probably have the structural environment $\left(\mathrm{R}_{2} \mathrm{SiO}\right)_{\mathrm{K}},{ }^{25}$ and suggesting consistent with the backbone structures shown in Scheme 2 .

Properties of Polymers. We examined absorption and excitation as well as fluorescence emission spectra of the polymers in solution. Typical absorption spectrum of the polymer 4a in THF is shown in Figure 1 as a dotted line. The maximum absorption band for $4 \mathrm{a}$ is observed at $263 \mathrm{~nm}$ with the band of 232-310 nm and molar absorptivity of 23,904 $\mathrm{cm}^{-1} \mathrm{M}^{-1}$. The absorption spectra of $4 \mathrm{~b}-\mathrm{e}$ exhibit strong absorption peaks at $\lambda_{\max }$ ranging from 275 to $341 \mathrm{~nm}$. These strong absorption bands in the UV-Vis spectra of ti-e may be attributed to the aryl groups along the polymer backbone. ${ }^{4}$ The maximum absorption wavelength of $4 \mathbf{d}$ is longer than those of other polycarbosiloxanes 4:-c and te probably due to the presence of naphthalene groups along the polymer main chain.

The excitation spectrum for $4 \mathrm{a}$ at the detection wavelength of $346 \mathrm{~nm}$ shows a strong excitation peak at $\lambda_{\mathrm{ex}, \max } 258 \mathrm{~nm}$ (Table 1). A typical excitation spectrum of the polymer $4 \mathbf{a}$ in THF solution is shown in Figure 1 as a dashed line. The excitation spectra of $\mathbf{4 b - e}$ at the detection wavelength of $302,300,448$, and $316 \mathrm{~nm}$ also exhibit strong excitation peaks at $\lambda_{\mathrm{ex}, \max }$ of $263,253,325$, and $263 \mathrm{~nm}$, respectively (Table 1). These strong excitation bands in the excitation spectra of the polymers 4ale may be attributed to the aryl groups along the polymer backbone. ${ }^{+}$The maximum excitation wavelength of $\mathbf{4 d}$ is longer than those of other polycarbosiloxanes 4a-c and $4 \mathrm{e}$ probably due to the presence of naphthalene groups along the polymer main chain.

The fluorescence emission spectrum for $4 \mathbf{a}$ at the excitation wavelength of $253 \mathrm{~nm}$ in THF solution reveals a strong emission peak at $\lambda_{\mathrm{em}, \max } 351 \mathrm{~nm}$ (Table 1). A typical fluorescence spectrum of the polymer $4 a$ in the THF solution is shown in Figure 1 as a solid line. The fluorescence spectra of $4 \mathrm{~b}-\mathrm{e}$ at the excitation wavelength of $263,253,341$, and 263 nm show strong emission peaks at the $\lambda_{\text {em. nax }}$ of 302,300 , 420 , and $316 \mathrm{~nm}$, respectively (Table 1). These strong emission bands in the fluorescence spectra of the polymers may be ascribed to the fluorophore of aryl groups along the polymer backbone. ${ }^{4}$ The maximum fluorescence emission wavelength of $\mathbf{4 d}$ is longer than those of other polycarbosiloxanes 4:-c and 4e. Both excitation and fluorescence emission spectra of the polymers imply that the polycarbosiloxanes 4a-e have chromophores containing the aryl functional groups along the polymer main chains. ${ }^{+}$Ultrafast time-resolved kinetic study may be required in order to further investigate the electronic conjugation properties of the prepared materials.

The thermal stabilities of polycarbosiloxanes 4a-e in a nitrogen atmosphere were evaluated by thermogravimetric analysis (TGA) with a heating rate of $10^{\circ} \mathrm{C} / \mathrm{min}$ (Figure 2). Polymer 4a is stable up to $200^{\circ} \mathrm{C}$ with only $1 \%$ loss of the

Table 1. Selected Properties of the Polycarbosiloxanes 4a-e

\begin{tabular}{|c|c|c|c|c|c|c|c|}
\hline Polymer & $\begin{array}{c}M_{11} / M_{n}{ }^{u} \\
\text { (PDI) }\end{array}$ & $\begin{array}{l}{ }^{29} \mathrm{Si} \mathrm{NMR}{ }^{b} \\
\delta \text { (ppm) }\end{array}$ & $\begin{array}{c}\mathrm{IR}^{\mathrm{k}} \\
l_{(\mathrm{si}-\mathrm{r}, \mathrm{C})}\left(\mathrm{cm}^{-\mathrm{l}}\right)\end{array}$ & $\begin{array}{c}\text { Absorption } \\
\lambda_{\text {abs, max }}(\varepsilon) \\
\left(\operatorname{nin}\left(\mathrm{cm}^{-1} \mathrm{M}^{-1}\right)\right)\end{array}$ & $\begin{array}{l}\text { Excitation } \\
\lambda_{\text {cx. max }}(\mathrm{nm})\end{array}$ & $\begin{array}{l}\text { Fluorescence } \\
\hat{\lambda}_{\mathrm{mm} \max }(\mathrm{nm})\end{array}$ & $\mathrm{TGA}^{g}$ \\
\hline $4 a$ & $\begin{array}{c}8,750 / 7.479 \\
(1.17)\end{array}$ & -9.21 & 1070 & $263(23,904)$ & 258 & 351 & 43 \\
\hline $4 \mathrm{~b}$ & $\begin{array}{c}3,510 / 2,250 \\
(1.56)\end{array}$ & -9.18 & 1082 & $281(55,800)$ & 263 & 302 & 42 \\
\hline $4 c$ & $\begin{array}{c}6,500 / 5,865 \\
(1.11)\end{array}$ & -9.13 & 1051 & $275(18,344)$ & 253 & 300 & 24 \\
\hline $4 d$ & $\begin{array}{c}4,840 / 2,830 \\
(1.71)\end{array}$ & -8.38 & 1075 & $341(45,156)$ & 325 & 420 & 62 \\
\hline $4 e$ & $\begin{array}{c}5,000 / 2,659 \\
(1.88)\end{array}$ & -9.21 & 1053 & $294(47,856)$ & 263 & 316 & 63 \\
\hline
\end{tabular}

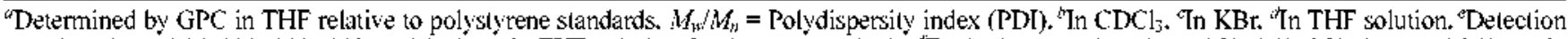
wavelengths ai $346,302,300,448$, and $316 \mathrm{~nm}$ in THF solution for 4a-c, respectively, ${ }^{t}$ Excitation wavelengths at $253,263,253,341$, and $263 \mathrm{~nm}$ in Tा $\Gamma$ solution for $4 a-e$, respectively. ${ }^{k} \%$ Weight remaining at $400{ }^{\circ} \mathrm{C}$ in nitrogen. 


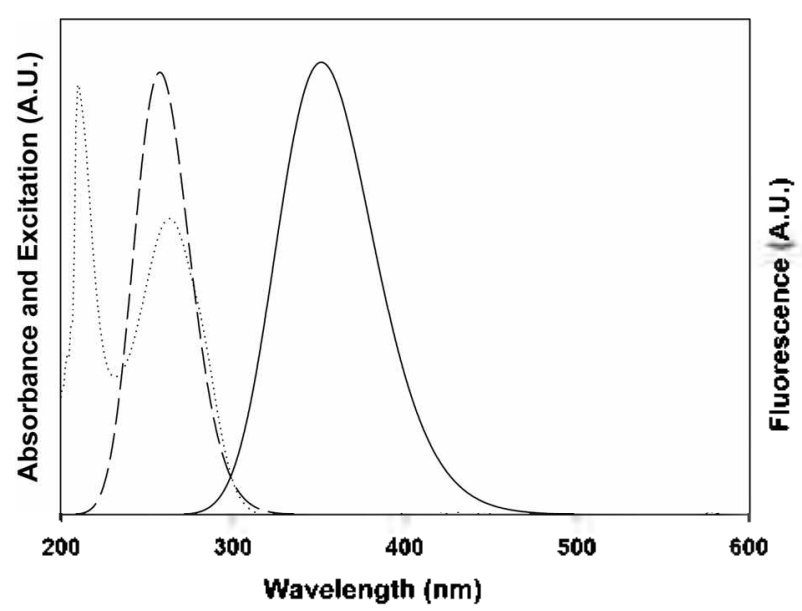

Figure 1. Absorbance (dotted linc, $\lambda_{\max }=263 \mathrm{nu}$ ), cxcitation (dashed line, $\lambda_{\text {del }}=346 \mathrm{nin}$ ) and fluorescence (solid line, $\lambda_{\mathrm{ex}}=255$ $\mathrm{nm}$ ) spectra of the polymer $\mathbf{4 a}$ in THF.

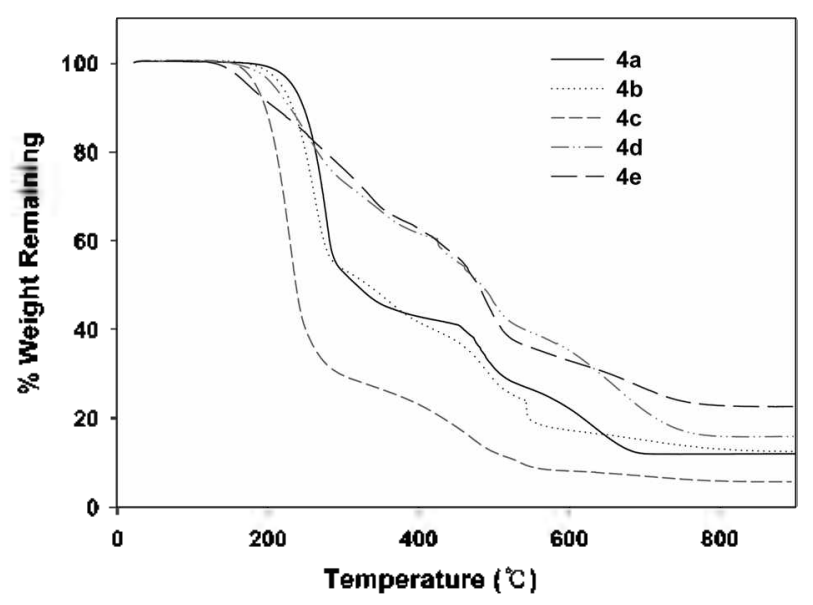

Figure 2. TGA thermograms of the polymers 4a-e in nitrogen.

initial weight in nitrogen. Weight loss of polymer 4a occurs rapidly upon heating above $200{ }^{\circ} \mathrm{C}$. Rapid weight loss of $53 \%$ of the initial weight occurs between 200 and $350^{\circ} \mathrm{C}$. Additionally weight loss of $19 \%$ of the initial weight occurs between 450 and $600^{\circ} \mathrm{C}$. When $4 \mathrm{a}$ is heated to $900^{\circ} \mathrm{C}, 88 \%$ of the initial weight of $4 \mathrm{a}$ is lost, and about $12 \%$ of char yield is observed. The polymer $4 \mathrm{~b}$ is stable up to $200^{\circ} \mathrm{C}$ with only $2 \%$ loss of the initial weight. Rapid weight loss of $50 \%$ of the initial weight occurs between 200 and $350{ }^{\circ} \mathrm{C}$. Additional weight loss of $20 \%$ of the initial weight occurs between 450 and $600^{\circ} \mathrm{C}$. When $4 \mathrm{~b}$ is heated to $900{ }^{\circ} \mathrm{C}, 88 \%$ of the initial weight of $\mathbf{4 b}$ is lost, and $12 \%$ of char yield is observed. The polymer $4 \mathrm{c}$ is stable up to $200^{\circ} \mathrm{C}$ with $9 \%$ loss of the initial weight. Rapid weight loss of $65 \%$ of the initial weight occurs between 200 and $350^{\circ} \mathrm{C}$. Additional weight loss of $10 \%$ of the initial weight occurs between 450 and $600^{\circ} \mathrm{C}$. When $4 \mathrm{c}$ is heated to $900^{\circ} \mathrm{C}, 94 \%$ of the initial weight of $4 \mathrm{c}$ is lost, and $6 \%$ of char yield is observed. The polymer $4 \mathrm{~d}$ is stable up to $200^{\circ} \mathrm{C}$ with $4 \%$ loss of the initial weight. Slow weight loss of $30 \%$ of the initial weight occurs between 200 and $350^{\circ} \mathrm{C}$. Additional weight loss of $20 \%$ of the initial weight occurs between 450 and $600^{\circ} \mathrm{C}$. When $4 d$ is heated to $900{ }^{\circ} \mathrm{C}, 84 \%$ of the intial weight of $\mathbf{4 d}$ is lost, and $16 \%$ of char yield is observed. The polymer $4 \mathrm{e}$ is stable up to $200{ }^{\circ} \mathrm{C}$ with $9 \%$ loss of the initial weight. Slow weight loss of $7 \%$ of the initial weight occurs between 200 and 350 ${ }^{\circ} \mathrm{C}$. Additionally slow weight loss of $24 \%$ of the initial weight occurs between 450 and $600^{\circ} \mathrm{C}$. When $4 \mathrm{e}$ is heated to $900{ }^{\circ} \mathrm{C}, 77 \%$ of the initial weight of $4 \mathrm{e}$ is lost, and $23 \%$ of char yield is observed.

All the resulting polymers $4 \mathrm{a}-\mathrm{e}$ are stable up to $200^{\circ} \mathrm{C}$ with weight loss of less than $9 \%$ in nitrogen and about $24-$ $63 \%$ of the initial polymer weights remain at $400^{\circ} \mathrm{C}$ in nitrogen as indicated in Figure 2 and Table 1.

\section{Conclusion}

We have successfully prepared poly(carbomethyloctylsiloxane)s containing fluorescent aromatic groups in the main chain, poly(oxybiphenyloxymethyloctylsilane), poly(oxy (4,4'-isopropylidene)diphenyleneoxymethyloctylsilane), poly(oxy $\left(4,4^{\prime}\right.$-hexafluoroisopropylidene) diphenyleneoxymethyloctylsilane), poly(oxy-2,6-naphthalenediyloxymethyloctylsilane), and poly(oxyphenyleneoxymethyloctylsilane), by the melt copolymerizations of bis(diethylamino)methyloctylsilane with several aryldiols of 4,4-biphenol, 4,4-isopropylidenediphenol, 4,4'-hexafluoroisopropylidenediphenol, 2,6-dihydroxynaphthalene, and hydroquinone. The materials are soluble in common organic solvents such as $\mathrm{CHCl}_{3}$ and THF. The polymers were characterized by using several spectroscopic methods in the solution states. In particular, FTIR spectra of all the polymeric materials show that the characteristic Si-O-C stretching frequencies appear at 1051-1082 $\mathrm{cm}^{-1}$. The materials in the THF solution show strong maximum absorption bands at $263-341 \mathrm{~nm}$, strong maximum excitation peaks at $253-325 \mathrm{~nm}$, and strong maximum emission bands at $300-420 \mathrm{~nm}$. All the absorption, excitation, and emission spectra imply that the obtained polycarbosiloxanes contain the aromatic chromophore groups in the polymer main chain. All these polymers are stable up to $200^{\circ} \mathrm{C}$ with weight loss of less than $9 \%$ in nitrogen, according to TGA. Ultrafast time-resolved kinetic studies may be helpful in further investigation of the electronic conjugation properties of these materials.

\section{Experimental Section}

General Procedures. All chemicals were purchased from Aldrich Chemicals Inc. All solvents were purified prior to use according to standard literature methods: $n$-hexane was distilled from sodium benzophenone ketyl and diethylamine from potassium hydroxide. ${ }^{28}$ All glassware was assembled and then flame-dried while being swept with argon. Reactions were monitored by Hewlett Packard 5890II analytical GLC equipped with HP-I capillary column $0.53 \mathrm{~mm} \times 30$ m) coated with cross-linked methyl silicon gum and flame ionization detector (FID). The column was deactivated immediately before use by injection of $10 \mu \mathrm{L}$ of hexamethyldisilazane. ${ }^{1} \mathrm{H},{ }^{13} \mathrm{C}$, and ${ }^{29} \mathrm{Si}$ nuclear magnetic resonance 
(NMR) spectroscopy were performed on a Bruker ARX-400 or a Bruker DRX Avance $400 \mathrm{MHz}$ FT-NMR spectrometers or a Varian Unity INOVA $500 \mathrm{MHz}$ FT-NMR spectrometer at the Daegu Center of the Korea Basic Science Institute using $\mathrm{CDCl}_{3}$ as solvent. Chemical shifts were measured using tetramethylsilane as an internal standard or the residual proton signal of the solvent as standard. IR spectra were recorded by a Shimadzu IR 430 spectrometer or a Bruker IFS-48 FT-IR spectrometer. Low-resolution mass spectra were recorded by GC/MS, using a Hewlett Packard $5890 \mathrm{II}$ gas chromatography equipped with a Hewlett Packard 5971 A mass selective detector by EI ionization at $70 \mathrm{eV}$. UV-vis absorption spectra were obtained on a Hewlett Packard 8453 spectrophotometer. Excitation and fluorescence emission spectra were taken on a Spex Fluorolog-311 fluorescence spectrophotometer. Gel permeation chromatography (GPC) analyses were performed on a Waters 1525 pump and Breeze software system with a Waters Styragel HR 3 column and refractive index detector at $40^{\circ} \mathrm{C}$. The eluent was THF at a flow rate of $1.0 \mathrm{~mL} / \mathrm{min}$. Calibration was done with a series of monodispersed polystyrene standards: $M_{\mathrm{p}} 580,3250,10100$, and 28500 whose $M_{\mathrm{w}} \cdot M_{\mathrm{n}}$ are less than 1.2. Thermogravimetric analysis (TGA) of polymer samples was performed on a TGA- 50 Shimadzu thermal analysis system. The temperature was increased at the heating rate of $10^{\circ} \mathrm{C} / \mathrm{min}$ from room temperature to 900 ${ }^{\circ} \mathrm{C}$ with nitrogen flow rate of $20 \mathrm{~mL} / \mathrm{min}$. Elemental analyses were performed using a Fisons EA 1108 elemental analyzer.

Bis(diethylamino)methyloctylsilane (2). A $500 \mathrm{~mL}$ three-necked, round bottomed flask was equipped with a reflux condenser, a pressure equalizing addition funnel with an inert gas inlet, and a Teflon covered magnetic stirring bar. The flask was charged with diethylamine $(33.6 \mathrm{~g}, 0.400 \mathrm{~mol})$ and hexane $(150 \mathrm{~mL})$ under an argon atmosphere. The mixture was placed in an ice bath. Dichloromethyloctylsilane $1(22.7 \mathrm{~g}, 0.100 \mathrm{~mol})$ were placed into the addition funnel and added dropwise over a period of $1 \mathrm{~h}$ to the well stirred and cooled reaction mixture. After the addition was completed, the ice bath was replaced by a heating mantle. The reaction mixture was well stirred at room temperature for an additional $12 \mathrm{~h}$ and then at $100{ }^{\circ} \mathrm{C}$ for $2 \mathrm{~h}$. The reaction was monitored by GLC. The white semi-solid reaction mixture was added with $n$-hexane $(50 \mathrm{~mL})$, filtered to remove the solid diethylamine hydrochloride salt, and the volatile solvent removed by simple distillation. The crude product was purified by fractionally distillation under reduced pressure to give $2,22.4 \mathrm{~g}(75.0 \%)$; bp $120^{\circ} \mathrm{C} / 1.0$ mmHg; ${ }^{1} \mathrm{H}-\mathrm{NMR}\left(400 \mathrm{MHz}, \mathrm{CDCl}_{3}\right): \delta 0.04(\mathrm{~s}, 3 \mathrm{H}), 0.56-$ $1.30(\mathrm{~m}, 17 \mathrm{H}), 0.98(\mathrm{t}, J=7.2 \mathrm{~Hz}, 6 \mathrm{H}), 2.81(\mathrm{q}, J=7.2 \mathrm{~Hz}$, $4 \mathrm{H}) ;{ }^{13} \mathrm{C}-\mathrm{NMR}\left(100 \mathrm{MHz}, \mathrm{CDCl}_{3}\right): \delta-3.15,14.13,15.15$, $15.50,22.74,23.76,29.37,29.42,32.01,33.92,39.16 ;{ }^{29} \mathrm{Si}-$ NMR (99 MHz, $\left.\mathrm{CDCl}_{3}\right): \delta-4.71$; IR (KBr disk): $v 2961$, $2924,2854,1465,1372,1251,1204,1175,1023,927,789$ $\mathrm{cm}^{-1}$; MS: $m / z$ (relative intensity) $302(1.3), 301(5.2), 300$ $\left(21, \mathrm{M}^{+}\right), 285\left(20, \mathrm{M}^{+}-\mathrm{CH}_{3}\right), 271\left(12, \mathrm{M}^{+}-\mathrm{CH}_{3} \mathrm{CH}_{2}\right), 187$ $\left(84, \mathrm{M}^{+}-\left(\mathrm{CH}_{2}\right)_{7} \mathrm{CH}_{3}\right)$.

Poly(oxybiphenyloxymethyloctylsilane) (4a). A $50 \mathrm{~mL}$ round bottomed flask was equipped with a heating mantle, a reflux condenser with an inert gas inlet, and a Teflon covered magnetic stirring bar. The flask was charged with 2 $(3.00 \mathrm{~g}, 10.0 \mathrm{mmol})$ and $4,4^{\prime}$-biphenol (3a) $(1.86 \mathrm{~g}, 10.0$ mmol) under an argon atmosphere. The reaction mixture was stirred at $130^{\circ} \mathrm{C}$ for $12 \mathrm{~h}$, at $200^{\circ} \mathrm{C}$ for $10 \mathrm{~h}$, and finally at $260^{\circ} \mathrm{C}$ for $2 \mathrm{~h}$ under an argon atmosphere. The reaction mixture was then allowed to cool to room temperature. The crude polymeric material was dissolved with a minimum amount of THF and precipitated with addition of methanol. After being separated by centrifuge, dried at room temperature, and then put under reduced pressure, the polymeric product 4 a was obtained as a brownish solid state which was almost soluble in the usual organic solvents such as THF and $\mathrm{CHCl}_{3}$. In this way, $2.50 \mathrm{~g}, 74.0 \%$ yield of $4 \mathrm{a}$ was prepared. 'H-NMR ( $\left.400 \mathrm{MHz}, \mathrm{CDCl}_{3}\right): \delta 0.03(\mathrm{~s}, 3 \mathrm{H}), 0.53-1.28$ (brs, $17 \mathrm{H}), 6.89-6.94(\mathrm{~m}, 4 \mathrm{H}), 7.39-7.43(\mathrm{~m}, 4 \mathrm{H}) ;{ }^{13} \mathrm{C}-\mathrm{NMR}(100$ $\left.\mathrm{MHz}, \mathrm{CDCl}_{3}\right): \delta 0.41,14.54,17.67,22.83,23.11,29.69$, $29.74,32.36,33.54,115.99,120.51,127.99,128.37 ;{ }^{29} \mathrm{Si}-$ NMR (99 MHz, $\left.\mathrm{CDCl}_{3}\right): \delta-9.21$; $\mathbb{R}(\mathrm{KBr}): v 3033,2925$, $2855,1607,1498,1254,1162,1070\left(v_{\mathrm{Si}-O_{C}}\right), 1024,921,821$ $\mathrm{cm}^{-1}$; UV (THF) $\lambda_{\max } \mathrm{nm}(\varepsilon): 263\left(23,904 \mathrm{~cm}^{-1} \mathrm{M}^{-1}\right)$; Elem. Anal. Calcd for $\left(\mathrm{C}_{21} \mathrm{H}_{28} \mathrm{SiO}_{2}\right)_{\mathrm{n}}: \mathrm{C}, 74.07 ; \mathrm{H}, 8.25$. Found: $\mathrm{C}$, $73.24 ; \mathrm{H}, 8.33$.

Poly(oxy(4,4'-isopropylidene)diphenyleneoxymethyloctylsilane) (4b) was prepared in a manner similar to that for the synthesis of $4 \mathrm{a}$, using $2(3.00 \mathrm{~g}, 10.0 \mathrm{mmol})$ and 4,4 isopropylidenediphenol (3b) ( $2.28 \mathrm{~g}, 10.0 \mathrm{mmol})$. Polymeric material $4 \mathrm{~b}, 3.20 \mathrm{~g}, 84.0 \%$, was obtained as a pale yellowish solid state and soluble in usual organic solvents such as THF and $\mathrm{CHCl}_{3} .{ }^{1} \mathrm{H}-\mathrm{NMR}\left(400 \mathrm{MHz}, \mathrm{CDCl}_{3}\right): \delta 0.25(\mathrm{~s}, 3 \mathrm{H})$, $0.52-1.29$ (brs, $17 \mathrm{H}), 1.65(\mathrm{~s}, 6 \mathrm{H}), 6.72-6.79(\mathrm{~m}, 4 \mathrm{H}), 7.06-$ $7.13(\mathrm{~m}, 4 \mathrm{H}) ;{ }^{13} \mathrm{C}-\mathrm{NMR}\left(100 \mathrm{MHz}, \mathrm{CDCl}_{3}\right): \delta 0.08,14.55$, $16.49,17.68,23.06,23.39,29.69,31.47,32.37,33.81$, $42.12,115.10,128.34,143.72,153.62 ;{ }^{29} \mathrm{Si}-\mathrm{NMR}(99 \mathrm{MHz}$, $\left.\mathrm{CDCl}_{3}\right): \delta-9.18$; $\mathbb{R}(\mathrm{KBr}): \vee 3034,2962,2856,1607,1505$, $1463,1254,1177,1100,1082$ ( $\nu_{\text {Si-OC. }}$ ), 1015, 930, $838 \mathrm{~cm}^{-1}$; UV (THF) $\lambda_{\text {max }} \mathrm{nm}(\varepsilon): 281\left(55,800 \mathrm{~cm}^{-1} \mathrm{M}^{-1}\right)$; Elem. Anal. Calcd for $\left(\mathrm{C}_{24} \mathrm{H}_{34} \mathrm{SiO}_{2}\right)_{\mathrm{n}}: \mathrm{C}, 75.34 ; \mathrm{H}, 8.96$. Found: $\mathrm{C}, 74.77$; $\mathrm{H}, 9.04$.

Poly(oxy (4,4'-hexafluoroisopropylidene) diphenyleneoxymethyloctylsilane) $(\mathbf{4 c})$ was prepared in a manner similar to that for the synthesis of $4 \mathrm{a}$, using $2(3.00 \mathrm{~g}, 10.0$ mmol) and 4,4'-hexafluoroisopropylidenediphenol (3b) $(3.36 \mathrm{~g}, 10.0 \mathrm{mmol})$. Polymeric material $4 \mathrm{c}, 3.50 \mathrm{~g}, 85.0 \%$, was obtained as a brown solid state and soluble in usual organic solvents such as THF and $\mathrm{CHCl}_{3}{ }^{1} \mathrm{H}-\mathrm{NMR}(400$ $\left.\mathrm{MHz}, \mathrm{CDCl}_{3}\right): \delta 0.25(\mathrm{~s}, 3 \mathrm{H}), 0.52-1.29$ (brs, $\left.17 \mathrm{H}\right), 6.83-$ $6.88(\mathrm{~m}, 4 \mathrm{H}), 7.25-7.30(\mathrm{~m}, 4 \mathrm{H}) ;{ }^{13} \mathrm{C}-\mathrm{NMR}(100 \mathrm{MHz}$, $\left.\mathrm{CDCl}_{3}\right): \delta 0.08,14.51,16.40,17.81,18.05,23.11,29.70$, $33.47,33.70,62.48,115.41,126.61,132.11,156.22$; ${ }^{29} \mathrm{Si}-$ NMR (99 MHz, $\left.\mathrm{CDCl}_{3}\right): \delta-9.13$; $\mathrm{R}(\mathrm{KBr}): v 3033,2959$, $2926,2875,2857,1614,1516,1457,1256,1206,1172$, 1051 ( $\left.v_{\text {Si- }-1}\right), 1018,925,833 \mathrm{~cm}^{-1}$; UV (THF) $\lambda_{\max } \mathrm{nm}(\varepsilon)$ : $275\left(18,344 \mathrm{~cm}^{-1} \mathrm{M}^{-1}\right)$; Elem. Anal. Calcd for $\left(\mathrm{C}_{24} \mathrm{H}_{28} 8 \mathrm{SiO}_{2} \mathrm{~F}_{6}\right)_{\mathrm{n}}$ : C, 58.76; H, 5.75. Found: C, 57.78; H, 5.89.

Poly(oxy-2,6-naphtalenediyloxymethyloctylsilane) (4d) 
was prepared in a manner similar to that for the synthesis of $4 a$, using $2(3.00 \mathrm{~g}, 10.0 \mathrm{mmol})$ and 2,6-dihydroxynaphthalene (3d) $(1.60 \mathrm{~g}, 10.0 \mathrm{mmol})$. Polymeric material $4 \mathrm{~d}, 1.50 \mathrm{~g}$, $44.0 \%$, was obtained as a dark brown viscous liquid state and soluble in usual organic solvents such as THF and $\mathrm{CHCl}_{3},{ }^{1} \mathrm{H}-\mathrm{NMR}\left(400 \mathrm{MHz}, \mathrm{CDCl}_{3}\right): \delta 0.25(\mathrm{~s}, 3 \mathrm{H}), 0.54-$ 1.28 (brs, $17 \mathrm{H}), 7.08-7.54(\mathrm{~m}, 6 \mathrm{H}) ;{ }^{13} \mathrm{C}-\mathrm{NMR}(100 \mathrm{MHz}$, $\left.\mathrm{CDCl}_{3}\right): \delta 0.01,14.53,16.30,17.67,23.10,29.69,31.37$, $32.36,33.53,115.41,126.61,132.11,156.22 ;{ }^{29}$ Si-NMR $(99$ $\left.\mathrm{MHz}, \mathrm{CDCl}_{3}\right): \delta-8.38$; IR (KBr): $v 3030,2957,2924,2854$, $1601,1506,1464,1375,1258,1246,1075$ ( $\left.\mathrm{V}_{\mathrm{Si}-\mathrm{O}-\mathrm{C}}\right), 1018$, $965,858 \mathrm{~cm}^{-1}$; UV (THF) $\lambda_{\max } \operatorname{nm}(\varepsilon): 341\left(45,156 \mathrm{~cm}^{-1}\right.$ $\left.\mathrm{M}^{-1}\right)$; Elem. Anal. Calcd for $\left(\mathrm{C}_{19} \mathrm{H}_{26} \mathrm{SiO}_{2}\right)_{n}: \mathrm{C}, 72.56 ; \mathrm{H}$, 8.33. Found: C, $71.64 ; \mathrm{H}, 8.58$.

Poly(oxyphenyleneoxymethyloctylsilane) (4e) was prepared in a manner similar to that for the synthesis of $4 \mathbf{a}$, using $2(3.00 \mathrm{~g}, 10.0 \mathrm{mmol})$ and hydroquinone (3d) $(1.10 \mathrm{~g}$, $10.0 \mathrm{mmol}$ ). Polymeric material $4 \mathrm{e}, 0.80 \mathrm{~g}, 30.0 \%$, was obtained as a dark brown viscous liquid state and soluble in usual organic solvents such as THF and $\mathrm{CHCl}_{3} .{ }^{1} \mathrm{H}-\mathrm{NMR}$ (400 $\left.\mathrm{MHz}, \mathrm{CDCl}_{3}\right): \delta 0.18$ (s, 3H), 0.52-1.27 (brs, $17 \mathrm{H}$ ), 6.68-6.75 (m, 4H); ${ }^{13} \mathrm{C}-\mathrm{NMR}\left(100 \mathrm{MHz}, \mathrm{CDCl}_{3}\right): \delta 0.07$, $14.54,16.25,17.68,23.28,29.66,31.38,32.34,33.54$, $116.27,116.56,120.76,121.03 ;{ }^{29} \mathrm{Si}-\mathrm{NMR} \quad(99 \mathrm{MHz}$, $\left.\mathrm{CDCl}_{3}\right): \delta-9.21$; IR $(\mathrm{KBr}): v 3039,2962,2924,2855,1610$, $1582,1506,1464,1406,1377,1238,1053$ ( $v_{\mathrm{Si}-0 . \mathrm{C}}$ ), 1012, $916,829 \mathrm{~cm}^{-1}$; UV (THF) $\lambda_{\max } \mathrm{nm}(\varepsilon): 294\left(47,856 \mathrm{~cm}^{-1}\right.$ $\left.\mathrm{M}^{-1}\right)$; Elem. Anal. Caled for $\left(\mathrm{C}_{15} \mathrm{H}_{24} \mathrm{SiO}_{2}\right)_{\mathrm{n}}: \mathrm{C}, 68.13 ; \mathrm{H}$, 9.15. Found: $\mathrm{C}, 67.65 ; \mathrm{H}, 9.03$. The excitation and fluorescence emission spectra in THF solution as well as TGA thermograms for polymers $\mathbf{4 a - 4 e}$ are described in Results and Discussion.

Acknowledgments. This work was supported by Keimyung University in 2008 .

\section{References}

1. Brook, M. A. In Silicon in Organic, Organometallic, and Polymer Chemistry; John Wiley \& Sons, Inc.: New York, 2000.

2. Clarson, S. J.; Semlyen, J. A. In Siloxane Polymers; PTR Prentice Hall, Inc.: Englewood Cliffs, New Jersey, 1993.
3. Jenekhe, S. A. Chem, Mater, 2004, 16, 4381 .

4. Barashkov, N. N.; Gunder, O. A. In Fhtorescent Pohnters; Ellis Horwood: London, UK, 1994.

5. Bisberg, J.; Cumming, W. J.; Gaudiana, R. A.; Hutchinson, K. D.; Ingwall, R. T.; Kolb, E. S.; Mehta, P. G.; Minns, R. A.; Petersen, C. P. Macromolectles 1995, 28, 386 .

6. Toulokhonova, I.; Bjerke-Kroll, B.; West, R. J. Organomet, Chem. $2003,686,101$.

7. Keller, T. D.; Homrighausen, C. L. J. Pohm. Sci, Part A: Poh:m. Chent 2002, 40,88.

8. Dias, F. B.; Lima, J. C.; Macanita, A.; Clarson, S. J.; Horta, A.; Pierola, I. Macromolecules 2000,33, 4772 .

9. Xu, C.; Wakamiya, A.; Yamaguchi, \$. J. Am. Chem. Soc. 2005, $127,1638$.

10. Son, H.-J.; Han, W.S.; Kim, H.; Kim, C.; Ko, J.; Lee, C.; Kang, S. O. Organometallics 2006, 25,766.

11. Backer, M. W; Pernisz, U. C. Polym. Prepr. (Am. Chem. Soc, Div, Polym. Chem.) 2001, 42(1), 122.

12. Chandrasekhar, V. In Inorganic and Organonetallic Pohmters; Springer-Verlag: Berlin, 2005.

13. Rubinsztain, S.; Cella J. A. Macromolectles 2005, 38, $106 \mathrm{I}$.

14. Cai, G.; Weber, W. P. Polym. Prepr. (An. Chem. Soc, Div. Polym. Chem.) 2001, 42(1), 171.

15. Nguyen, K.-A. T.; Shamshurin, A.; Clarke, S.; Matisons, J. Polym Prepr: (Am. Chem. Soc., Div. Polym. Chem.) 2004, 45(1), 706.

16. Carraher, C. E., Jr; Klimiuk, G. H. J. Polym. Sci, Port A-1: Pohm. Chem. 1970, 8(4), 973.

17. Lee, J. H.; Park, Y. T. Bull. Korean Chen. Soc. 2004, 25, 889.

18. Kim, M. H.; Park, Y, T. Bull. Korean Chem. Soc. 2005, 26, 488.

19. Kim, E. J.; Park, J. W.; Kim, Y,-R.; Park, Y. T. Bull. Korean Chem. Soc, $2003,24,484$.

20. Kim, J. H.; Park, Y. T. Bthl. Korean Chen. Soc. 2006, 27, 869.

2l. Hwang, I.-W.; Song, N. W; Kim, D.; Park, Y. T.; Kim, Y.-R. $J$. Pobnt. Sci., Part B: Polym. Phys. 1999, 37, 2901.

22. Choi, S. H.; Hwang, I.-W.; Kim, S. H.; Park, Y. T.; Kim, Y.-R. J. Polym. Sci., Part B: Polym. Phys, 2002, 40, 1298.

23. Padmanaban, M.; Kakimoto, M.; Imai, Y. J. Polym. Sci. Part A: Polyn. Chem. 1990, 28, 2997.

24. Pretsch, E.; Bühlmann, P,; Affolter, C. In Siructure Deternination of Organic Conipotinds, Tables of Spectrat Data, 3rd ed.; Springer-Verlag: Berlin, 2000.

25. Williams, E. A. NMR Spectroscopy of Organosilicon Compounds in The Chemistry: of Organic Silicon Complinds; Palai, S.; Rappoport, Z., Eds.; Wiley: Chichester, UK, 1989; Vol. I, Chapter 8.

26. Curry, J. K.; Byrd, J. D. J. Appl. Polym. Sci. 1965, 9, 295.

27. Bellamy, L. J. In The Infro-red of Conplex Molecules, 3rd ed.; John Wiley and Sons: New York, 1975.

28. Armarego, W. L. F.; Perrin, D. D. In Purification of Laboratory: Chemicals, 4th ed.; Butlerworth-Heinemann: Oxford, 1996. 